\title{
Pengaruh Kesadaran Wajib Pajak, Pelayanan Fiskus, dan Sanksi Pajak terhadap Kepatuhan Wajib Pajak Orang Pribadi yang Melakukan Kegiatan Usaha dan Pekerjaan Bebas di Kota Samarinda
}

\author{
Januar Dio Brata ${ }^{1}$, Isna Yuningsih ${ }^{2}$, Agus Iwan Kesuma ${ }^{3}$ \\ Fakultas Ekonomi dan Bisnis Universitas Mulawarman, Indonesia \\ Email: januardio@ rocketmail.com
}

\begin{abstract}
Abstrak
Jumlah wajib pajak dari tahun ke tahun semakin bertambah. Namun bertambahnya jumlah wajib pajak tersebut tidak diimbangi dengan kepatuhan wajib pajak dalam membayar pajak. Masalah kepatuhan tersebut menjadi kendala dalam pemaksimalan penerimaan pajak. Penelitian ini mengkaji tingkat kepatuhan wajib pajak orang pribadi yang melakukan kegiatan usaha dan pekerjaan bebas di Kota Samarinda dengan menggunakan beberapa variabel bebas seperti kesadaran wajib pajak, pelayanan fiskus, dan sanksi pajak. Populasi dalam penelitian ini adalah para wajib pajak orang pribadi yang melakukan kegiatan usaha dan pekerjan bebas yang ada di Kota Samarinda. Berdasarkan data dari KPP Pratama Samarinda, hingga Juli 2016 terdapat 35.445 wajib pajak orang pribadi yang melakukan kegiatan usaha dan pekerjan bebas. Pengambilan sampel dilakukan dengan metode incidental sampling. Jumlah sampel ditentukan sebanyak 100 orang. Metode pengumpulan data primer yang dipakai adalah dengan metode survei dengan menggunakan media kuesioner. Teknik analisis data yang digunakan dalam penelitian ini adalah teknik analisis regresi berganda. Berdasarkan hasil analisis yang dilakukan maka diperoleh kesimpulan bahwa kesadaran wajib pajak, dan sanksi pajak berpengaruh signifikan dan mempunyai hubungan positif terhadap kepatuhan wajib pajak. Sedangkan pelayanan fiskus memberikan pengaruh tidak signifikan dan mempunyai hubungan yang negatif terhadap kepatuhan wajib pajak.
\end{abstract}

Kata Kunci: Kepatuhan wajib pajak, kesadaran wajib pajak, pelayanan fiskus, dan sanksi pajak

\section{The Effect of Taxpayer Awareness, Fiscal Services, and Tax Sanctions on Compliance of Individual Taxpayers Conducting Business Activities and Free Employment in Samarinda City}

\begin{abstract}
The number of tax payers is increase for years. But, it is not balanced with the level of tax compliance. The compliance problem becomes an obstacle in optimizing the tax revenue. This study examines the level of compliance of individual taxpayers conducting business and professional services in Samarinda by using several independent variables such as awareness of the taxpayer, the service tax authorities and tax penalties. The population of this study is individual taxpayers conducting business and professional services in Samarinda. Based on data from the KPP Pratama Samarinda, until July 2016 there were 35.445 individual taxpayers conducting business and free job retention. Sampling was done by incidental sampling method. The number of sample is 100 people. Primary data collection method used is a survey method using questionnaires media. Data analysis techniques used in this study is the technique of multiple regression analysis. Based on the results of the analysis undertaken concluded that awareness of the taxpayer, and tax penalties had significant and positive impact on taxpayer compliance. The service tax authorities had no significant and negative impact on taxpayer compliance.
\end{abstract}

Keywords: Tax compliance, the taxpayer awareness, the service tax authorities and tax penalties. 


\section{Pengaruh Kesadaran Wajib Pajak, Pelayanan Fiskus, dan Sanksi Pajak; Januar Dio}

\section{PENDAHULUAN}

Pajak merupakan sumber penerimaan negara yang pasti dan mencerminkan kegotongroyongan masyarakat dalam membiayai negara. Saat ini sekitar 70\% APBN Indonesia dibiayai dari penerimaan pajak. Pada tahun 1983, pemerintah Indonesia menerapkan Self Assessment System yang memberikan kepercayaan kepada wajib pajak untuk mendaftar, menghitung, membayar dan melaporkan kewajiban perpajakannya sendiri sesuai dengan ketentuan Undang-Undang Perpajakan yang berlaku. Hal ini menjadikan kepatuhan dan kesadaran wajib pajak menjadi faktor yang sangat penting dalam hal untuk mencapai keberhasilan penerimaan pajak. Kepatuhan memenuhi kewajiban pajak secara sukarela merupakan tulang punggung dari Self Assessment System (Supadmi, 2010). Kepatuhan Pajak menurut Simon et al yang dikutip oleh Gunadi (2005) adalah wajib pajak mempunyai kesediaan untuk memenuhi kewajiban pajaknya sesuai dengan aturan yang berlaku tanpa perlu diadakannya pemeriksaan, investigasi seksama, peringatan ataupun ancaman, dalam penerapan sanksi baik hukum maupun administrasi

Kesadaran wajib pajak akan meningkat bilamana wajib pajak tersebut berpersepsi baik terhadap pajak itu sendiri. Dengan diterapkan self assessment system akan memberikan perubahan sikap kesadaran masyarakat dalam membayar pajak secara sukarela tanpa ada paksaan dari petugas fiskus (Darmayanti, 2004 dalam Suhendra, 2010). Dalam penelitian yang dilakukan oleh Indriyani (2014) menjelaskan bahwa kesadaran membayar pajak yang tinggi dapat mempengaruhi kepatuhan pelaporan wajib pajak badan. Hasil penelitian yang berbeda dikemukakan oleh Widayati dan Nurlis (2010) dan juga Utami dan Kardinal (2013) dimana kesadaran tidak berpengaruh terhadap kemauan membayar pajak.

Saat ini banyak instansi atau perusahaan yang berlomba-lomba meningkatkan kualitas pelayanannya, karena pelayanan secara tidak langsung memberikan kontribusi terhadap penjualan suatu produk, sehingga dapat meningkatkan pendapatan suatu instansi atau perusahaan tersebut. Hal yang sama juga berlaku untuk kualitas pelayanan yang akan diberikan oleh aparat pajak kepada wajib pajak. Apabila aparat pajak memberikan pelayanan terbaik kepada wajib pajak, secara otomatis wajib pajak akan merasa puas dengan pelayanan fiskus, sehingga secara otomatis dapat meningkatkan penerimaan pajak. Dalam penelitian yang dilakukan penelitian Winerungan (2013) yang menunjukkan pelayanan fiskus tidak memiliki pengaruh terhadap kepatuhan pajak. Hasil yang berbeda didapat dari penelitian yang dilakukan oleh Nugroho (2012) dan Indriyani (2014) dimana kualitas pelayanan berpengaruh terhadap kemauan membayar pajak dan kepatuhan pelaporan wajib pajak badan.

Banyak kasus di Indonesia wajib pajak ingin membayar pajak dengan mengecilkan besaran pajak terutang, maka dari itu wajib pajak tersebut melakukan kecurangan dengan dibantu oleh oknum pegawai pajak. Sanksi pajak harus lebih diperketat peraturannya, supaya wajib pajak akan merasa takut jika tidak membayar pajak dan akan melakukan perhitungan pajak sesuai dengan penghasilan yang diperoleh. Sanksi perpajakan dapat menjadi motivasi dalam meningkatkan kepatuhan wajib pajak dalam membayar pajak. Otoritas pajak harus konsisten dalam menerapkan sanksi bagi yang melanggar ketentuan membayar pajak. Dengan demikian, diharapkan penerimaan pajak akan meningkat. Variabel sanksi perpajakan dalam penelitian yang dilakukan oleh Indriyani (2014) menjelaskan bahwa adanya pengaruh dengan kepatuhan pelaporan wajib pajak badan. Hasil penelitian yang berbeda dapat dijelaskan oleh penelitian Masruroh (2013) dimana sanksi perpajakan tidak memiliki pengaruh terhadap kepatuhan wajib pajak.

Fokus Direktorat Jenderal Pajak tahun 2016 adalah Wajib Pajak Orang Pribadi, karena kontribusi dari Wajib Pajak Orang Pribadi yang masih sangat minim dibanding Wajib Pajak Badan yang menjadi penyumbang penerimaan pajak terbesar saat ini. Begitu pula upaya Kantor Wilayah Direktorat Jenderal Pajak Kalimantan Timur dan Kalimantan Utara yang memfokuskan strategi pemungutan pajak pada Orang Pribadi yang melakukan pekerjaan bebas, yakni pengusaha dan pelaku usaha mikro kecil dan menengah (UMKM) demi menggenjot penerimaan pajak. Hal ini dikarenakan pemungutan pajak karyawan perusahaan sudah dilakukan oleh perusahaannya, tidak seperti pengusaha yang hingga kini belum terkawal dengan baik. (Kaltim Post:30 Januari 2016:39).

Wajib pajak orang pribadi yang melakukan kegiatan usaha atau pekerjaan bebas juga lebih rentan terhadap pelanggaran pajak daripada wajib pajak orang pribadi yang tidak melakukan kegiatan usaha atau

Copyright @ 2017, FORUM EKONOMI ISSN Print: 1411-1713 ISSN Online: 2528-150X 
pekerjaan bebas. Hal tersebut dikarenakan mereka melakukan pembukuan atau pencatatan sendiri atas usaha mereka. Pembukuan atau pencatatan yang dilakukan dapat dilaksanakan sendiri maupun mempekerjakan orang yang ahli dalam akuntansi. Namun kebanyakan dari pelaku kegiatan usaha dan pekerjaan bebas tersebut beranggapan bahwa akan kurang efisien apabila mempekerjakan orang untuk melakukan pembukuan atau pencatatan, terutama dalam hal biaya. Dengan demikian, yang bersangkutan lebih memilih untuk menyelenggarakan pembukuan atau pencatatan sendiri, sehingga menimbulkan kemungkinan kesalahan maupun ketidakjujuran dalam pelaporan pajaknya (Arum, 2012).

Kepatuhan Wajib Pajak Provinsi Kalimantan Timur hingga bulan April 2015 bahkan menempati urutan kedua terendah Nasional (Direktorat Jenderal Pajak, 2015). Padahal di provinsi yang dikenal kaya ini terdapat banyak sekali perusahaan pertambangan, perkebunan, migas maupun industri lainnya yang berskala nasional bahkan internasional yang seharusnya meningkatkan pendapatan per kapita masyarakat serta menumbuhkan ekonomi di sekitarnya. Berbekal pengalaman penulis yang mengikuti Kuliah Kerja Nyata pada bagian Fungsional Pemeriksaan Kantor Pelayanan Pajak (KPP) Pratama Samarinda, penulis ingin mencari tahu lagi sebab-sebab ketidakpatuhan Wajib Pajak.

Berdasarkan data Kantor Pajak Pratama Samarinda menunjukkan bahwa meningkatnya jumlah wajib pajak yang terdaftar belum tentu menunjukkan peningkatan kepatuhan wajib pajak orang pribadi yang menyampaikan SPT Tahunan. Tingkat kepatuhan pada tahun 2012 sebesar $36 \%$ sama pada tahun berikutnya yaitu 36\%, dan pada tahun tahun 2014 menurun menjadi 35\%. Dengan tingkat kepatuhan yang stagnan bahkan menurun tersebut memberikan motivasi untuk dilakukannya penelitian mengenai beberapa faktor yang mempengaruhi kepatuhan wajib pajak dalam bentuk skripsi dengan judul "Pengaruh Kesadaran Wajib Pajak, Pelayanan Fiskus, dan Sanksi Pajak terhadap Kepatuhan Wajib Pajak Orang Pribadi yang Melakukan Kegiatan Usaha dan Pekerjaan Bebas Di Kota Samarinda".

\section{Pengaruh Kesadaran Wajib Pajak terhadap Kepatuhan Wajib Pajak}

Kesadaran wajib pajak adalah suatu kondisi dimana wajib pajak mengetahui, memahami dan melaksanakan ketentuan perpajakan dengan benar dan sukarela. Semakin tinggi tingkat kesadaran wajib pajak maka pamahaman dan pelaksanaan kewajiban perpajakan semakin baik sehingga dapat meningkatkan kepatuhan (Muliari dan Setiawan, 2010). Theory of Planned Behavior relevan untuk menjelaskan perilaku wajib pajak dalam memenuhi kewajiban perpajakannya. Sebelum individu melakukan sesuatu, individu tersebut akan memiliki keyakinan mengenai hasil yang akan diperoleh dari perilakunya tersebut. Kemudian yang bersangkutan akan memutuskan bahwa akan melakukannya atau tidak melakukannya. Hal tersebut berkaitan dengan kesadaran wajib pajak. Wajib pajak yang sadar pajak, akan memiliki keyakinan mengenai pentingnya membayar pajak untuk membantu menyelenggarakan pembangunan negara (behavioral beliefs). Berdasarkan uraian tersebut dapat dikatakan bahwa kesadaran wajib pajak diduga akan berpengaruh terhadap kepatuhan wajib pajak dalam membayar pajak. Oleh karena itu maka dirumuskan hipotesis sebagai berikut:

\section{H1 : Kesadaran wajib pajak berpengaruh positif terhadap kepatuhan wajib pajak}

\section{Pengaruh Pelayanan Fiskus terhadap Kepatuhan Wajib Pajak}

Kepatuhan wajib pajak dalam memenuhi kewajiban membayar pajak tergantung pada bagaimana petugas pajak memberikan mutu pelayanan yang terbaik kepada wajib pajak (Jatmiko, 2006). Pelayanan pajak dapat dikaitkan dengan normative beliefs yang merupakan salah satu faktor dari Theory of Planned Behavior. Normative beliefs menjelaskan ketika akan melakukan sesuatu, individu akan memiliki keyakinan tentang harapan normatif dari orang lain dan motivasi untuk memenuhi harapan tersebut. Dengan adanya pelayanan yang baik dari petugas pajak, sistem perpajakan yang efisien dan efektif, serta penyuluhan-penyuluhan pajak yang memberikan motivasi kepada wajib pajak agar taat pajak, akan membuat wajib pajak memiliki keyakinan atau memilih perilaku taat pajak. Berdasarkan uraian tersebut dapat dikatakan bahwa pelayanan fiskus diduga akan berpengaruh terhadap kepatuhan wajib pajak dalam membayar pajak. Oleh karena itu maka dirumuskan hipotesis sebagai berikut: 


\section{H2 : Pelayanan fiskus berpengaruh positif terhadap kepatuhan wajib pajak}

\section{Pengaruh Sanksi Pajak terhadap Kepatuhan Wajib Pajak}

Sanksi pajak dibuat dengan tujuan agar wajib pajak takut untuk melanggar Undang-undang Perpajakan. Wajib pajak akan mematuhi pembayaran pajaknya bila memandang bahwa sanksi akan lebih banyak merugikannya (Jatmiko, 2006). Sanksi pajak merupakan jaminan bahwa ketentuan peraturan perundang-undangan perpajakan (norma perpajakan) akan dituruti/ditaati/dipatuhi, dengan kata lain sanksi perpajakan merupakan alat pencegah agar wajib pajak tidak melanggar norma perpajakan (Mardiasmo, 2011:59). Sanksi pajak terkait dengan control beliefs yang merupakan salah satu faktor dari Theory of Planned Behavior. Kepatuhan wajib pajak akan ditentukan berdasarkan persepsi wajib pajak tentang seberapa kuat sanksi pajak mampu mendukung perilaku wajib pajak untuk taat pajak. Oleh karena itu, pandangan wajib pajak mengenai sanksi perpajakan diduga akan mempengaruhi kepatuhan wajib pajak dalam membayar pajak. Berdasarkan hal tersebut maka dirumuskan hipotesis sebagai berikut:

\section{H3 : Sanksi pajak berpengaruh positif terhadap kepatuhan wajib pajak}

\section{METODE PENELITIAN}

\section{Variabel Penelitian}

Penelitian ini dilakukan untuk mengetahui dampak kesadaran wajib pajak, pelayanan fiskus, dan sanksi perpajakan terhadap kepatuhan wajib pajak. Untuk mendapat hasil yang akurat, perlu dilakukan pengujian terhadap hipotesis-hipotesis yang ada. Penelitian ini menggunakan variabel dependen yaitu kepatuhan wajib pajak dan variabel independen yaitu kesadaran wajib pajak, pelayanan fiskus dan sanksi pajak.

\section{Populasi dan Sampel}

Populasi dalam penelitian ini adalah para Wajib Pajak Orang Pribadi yang melakukan kegiatan usaha dan pekerjaan bebas yang terdaftar di KPP Pratama Samarinda. Jumlah populasi dalam penelitian ini tercatat sebanyak 35.445 pada Juli 2016 (KPP Pratama Samarinda). Teknik pengambilan sampel ialah teknik incidental sampling yaitu teknik penentuan sampel berdasarkan kebetulan yaitu siapa saja yang secara kebetulan bertemu dengan peneliti dapat digunakan sebagai sampel, apabila orang yang kebetulan ditemui cocok sebagai sumber data (Sugiyono, 2012:96). Jumlah minimal sampel ditentukan dengan menggunakan rumus berikut (Muliari dan Setiawan, 2010):

$$
\begin{aligned}
\mathrm{n} \quad & \frac{\mathrm{N}}{1+\mathrm{N}(\text { moe })^{2}} \\
\mathrm{n} & =\frac{35.445}{1+35.445(10 \%)^{2}} \\
\mathrm{n} & =99,72 \\
\mathrm{n} & =100 \text { sampel }
\end{aligned}
$$

Keterangan:

$$
\begin{array}{ll}
\mathrm{n} & \text { : jumlah sampel } \\
\mathrm{N} & \text { : populasi } \\
\mathrm{Moe} & : \text { margin of error max yaitu tingkat kesalahan maksimum yang dapat ditoleransi } \\
& \quad(\text { ditentukan } 10 \%)
\end{array}
$$

\section{Jenis dan Sumber Data}

Jenis dan sumber data mendeskripsikan jenis data dan variabel penelitian. Jenis data yang digunakan berupa data primer yang berarti adalah data diperoleh secara langsung dari lapangan. Pada 
penelitian ini digunakan jenis data primer berupa kuesioner yang diberikan kepada respondendan kemudian akan diolah menggunakan software SPSS (Ghozali, 2011). Sumber data primer pada penelitian ini diperoleh langsung dari para WPOP yang melakukan usaha dan pekerjaan bebas yang berdomisili di Kota Samarinda.

\section{Metode Pengumpulan Data}

Pengumpulan data primer dilakukan dengan menggunakan media angket (kuesioner). Kuesioner yang dimaksud merupakan daftar pertanyaan yang harus dijawab oleh responden yang merupakan sampel dari penelitian. Responden akan menilai setiap pernyataan dengan menggunakan skala Likert 5 poin, dari persepsi responden bahwa responden sangat tidak setuju sampai dengan sangat setuju terhadap suatu pernyataan yang ada dalam kuesioner

\section{Analisis Regresi}

Analisis digunakan untuk menyederhankan data agar data lebih mudah diinpertrasikan. Analisis ini dilakukan dengan menggunakan teknik analisis regresi berganda untuk mengolah dan membahas data yang telah diperoleh dan menguji hipotesis yang diajukan. Teknik analisis regresi berganda dipilih untuk digunakan pada penelitian ini karena teknik regresi berganda dapat menyimpulkan secara langsung mengenai pengaruh masing-masing variabel bebas yang digunakan secara parsial ataupun secara bersamasama.

\section{HASIL DAN PEMBAHASAN}

\section{Gambaran Umum Wajib Pajak Orang Pribadi yang Melakukan Kegiatan Usaha dan Pekerjaan Bebas Di Kota Samarinda}

Jumlah wajib pajak yang menjadi responden dalam penelitian ini berdasarkan perhitungan Slovin adalah 100 responden. Waktu penyebaran kuesioner ini dilakukan mulai tanggal 8 September 2016 sampai dengan 23 September 2016. Dari 100 paket kuesioner yang disebarkan, 50 paket disebarkan pada Kantor Pelayanan Pajak (KPP) Pratama Samarinda, sedangkan 50 paket lainnya diberikan kepada responden secara langsung dengan cara mengunjungi kediaman atau tempat usaha responden bersangkutan. Responden tersebut terdiri dari Wiraswasta yang membuka usaha dengan nama sendiri sejumlah 80 orang, sedangkan 20 responden lainnya terdiri dari Dokter, Notaris, Pejabat Pembuat Akta Tanah, Konsultan Hukum dan Konsultan Pajak.

\section{Statistik Deskriptif}

Tabel 1. Statistik Deskriptif

Descriptive Statistics

\begin{tabular}{|c|c|c|c|c|c|c|}
\hline & $\mathrm{N}$ & Range & Minimum & Maximum & \multicolumn{2}{|r|}{ Mean } \\
\hline & Statistic & Statistic & Statistic & Statistic & Statistic & Std. Deviation \\
\hline $\mathrm{Y}$ & 100 & 20,00 & 5,00 & 25,00 & 19,5600 & 5,57831 \\
\hline $\mathrm{X} 1$ & 100 & 12,00 & 13,00 & 25,00 & 20,4600 & 2,25371 \\
\hline $\mathrm{X} 2$ & 100 & 15,00 & 15,00 & 30,00 & 23,3900 & 3,39011 \\
\hline $\mathrm{X} 3$ & 100 & 18,00 & 7,00 & 25,00 & 17,8500 & 3,37362 \\
\hline $\begin{array}{l}\text { Valid N } \\
\text { (listwise) }\end{array}$ & 100 & & & & & \\
\hline
\end{tabular}

Sumber: Data Olahan

Dari tabel 4.1 dapat disimpulkan bahwa $\mathrm{N}$ adalah jumlah responden yaitu 100. Variabel Kepatuhan Wajib Pajak mempunyai nilai minimum 5 dan nilai maksimum sebesar 25 dan nilai rata-rata 19,56. Variabel Kesadaran Wajib Pajak mempunyai nilai minimum 13 dan nilai maksimum sebesar 25 dan nilai rata-rata 20,46. Variabel Pelayanan Fiskus mempunyai nilai minimum 15 dan nilai maksimum 


\section{Pengaruh Kesadaran Wajib Pajak, Pelayanan Fiskus, dan Sanksi Pajak; Januar Dio

sebesar 30 dan nilai rata-rata 23,39 .Variabel Sanksi Pajak mempunyai nilai minimum 7 dan nilai maksimum sebesar 25 dan nilai rata-rata 17,85.

\section{Uji Validitas}

Adapun kriteria yang digunakan dalam menentukan valid atau tidaknya pernyataan yang digunakan dalam penelitian ini adalah apabila korelasi antara masing-masing indikator terhadap total skor konstruk menunjukan hasil yang signifikan dengan tingkat $\alpha=0,05$, df $=\mathrm{n}-2(100-2)=98, \mathrm{r}$ tabel $=$ 0,6319. Jika pearson correlation-nya memiliki nilai lebih besar dari 0,6319 , maka setiap item pertanyaan akan dinyatakan valid. Dari uji validitas terlihat bahwa setiap item pertanyaan menunjukkan pearson correlation di atas atau lebih besar dari $\mathrm{r}$ tabel yaitu 0,6319 , sehingga seluruh pertanyaan dalam penelitian ini dinyatakan valid.

\section{Uji Reliabilitas}

Variabel penelitian akan dikatakan reliabel, jika Cronbach Alpha-nya memiliki nilai lebih besar dari 0,6. Pada tabel 4.4, berikut akan menerangkan hasil pengujian reliabilitas dari instrumen untuk setiap variabel penelitian. Berdasarkan uji reliabilitas dapat dilihat bahwa koefisen cronbach alpha 0,924, 0,715, 0,764, dan 0,677 sehingga dapat disimpulkan bahwa seluruh instrumen dalam penelitian ini reliabel.

\section{Uji Asumsi Klasik}

\section{Uji Normalitas}

Uji normalitas data dilakukan untuk menguji apakah dalam model regresi, variebel pengganggu atau residual terdistribusi secara normal atau tidak. Dalam penelitian ini uji normalitas data dilakukan melalui pendekatan statistik, yakni test Kolmogorov-Sminov. Print Out analisis terlihat pada tabel berikut:

Tabel 2. Uji Normalitas

One-Sample Kolmogorov-Smirnov Test

\begin{tabular}{llr}
\hline & & $\begin{array}{c}\text { Unstandardized } \\
\text { Residual }\end{array}$ \\
\hline $\mathrm{N}$ & Mean & 100 \\
Normal Parameters &, 0000000 \\
& Std. & 4,78045933 \\
& Deviation & \\
Most Extreme Differences & Absolute &, 085 \\
& Positive &, 079 \\
Kolmogorov-Smirnov Z & Negative &,- 085 \\
Asymp. Sig. (2-tailed) & &, 853 \\
Sumber: Data Olahan & &, 461 \\
\hline
\end{tabular}

Hasil analisis menunjukkan bahwa Asymp. Sig. (2- tailed) sebesar 0,461 . Dengan demikian nilai signifikasinya lebih besar dari 0,05 sehingga dapat disimpulkan semua variabel berdistribusi normal.

\section{Uji Multikolinearitas}

Multikolinearitas artinya antara variabel independen yang terdalam dalam model memiliki hubungan yang sempurna / mendekati sempurna atau koefisien korelasinya tinggi. Metode untuk menguji ada tidaknya multikolinearitas dapat dilihat dari Variance Inflation Factor (VIF). Batas nilai VIF adalah 10. Apabila lebih dari 10 maka dapat disimpulkan terjadi multikolinearitas. (Ghozali, 2011: 105 - 106) 


\section{Tabel 3. Uji Multikolinearitas Coefficients $^{\mathrm{a}}$}

\begin{tabular}{llr}
\hline \multirow{2}{*}{ Model } & \multicolumn{2}{c}{ Collinearity Statistics } \\
\cline { 3 - 3 } & (Constant) & \multicolumn{2}{c}{ VIF } \\
\hline \multirow{3}{*}{1} & X1 & 1,191 \\
& X2 & 1,054 \\
& X3 & 1,197 \\
\hline
\end{tabular}

Sumber: Data Olahan

Berdasarkan tabel di atas menunjukkan nilai VIF (Variance Inflation Factor) seluruh variabelnya $<10$. Dapat disimpulkan bahwa model regresi tidak mengandung multikolinearitas.

\section{Uji Heteroskedastisitas}

Uji heteroskedastisitas bertujuan menguji apakah dalam model regresi terjadi ketidaksamaan variance dari residual satu pengamatan ke pengamatan lainnya. Tidak terjadi heteroskedastisitas apabila tidak ada pola yang jelas, serta titik - titik menyebar di atas dan di bawah angka 0 pada sumbu Y. (Ghozali, 2011 : 139-143).

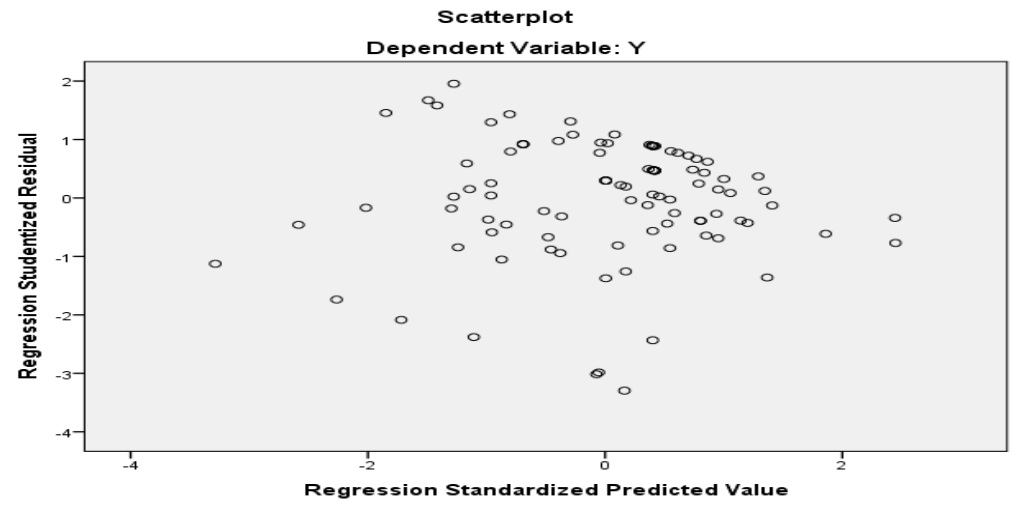

Gambar 1. Uji Heteroskedastisitas

Gambar diatas yang menunjukkan bahwa titik - titik observasi data penelitian tersebar diantara angka 0 pada sumbu $\mathrm{X}$ dan $\mathrm{Y}$, sehingga dapat dinyatakan bahwa tidak terjadi gejala heteroskedastisitas dalam model regresi.

\section{Uji Autokorelasi}

Uji autokorelasi merupakan suatu gejala adanya korelasi diantara semua variabel dari serangkaian observasi yang disusun menurut urutan waktu, juga adanya korelasi antara variabel pengganggu. Menurut Algifari (2000: 89) untuk mengadopsi adanya model regresi dilakukan uji Durbin Watson (Uji Dw). Hasil pengujian Durbin Watson kemudian dibandingkan dengan kriteria Autokorelasi. Adapun hasil pengujian Durbin Watson adalah sebagai berikut:

Tabel 4. Uji Autokorelasi

Model Summary

\begin{tabular}{|c|c|c|c|c|}
\hline \multirow[t]{2}{*}{ Model } & \multicolumn{3}{|c|}{ Change Statistics } & \multirow[t]{2}{*}{ Durbin-Watson } \\
\hline & df1 & $\mathrm{df} 2$ & Sig. F Change & \\
\hline 1 & $3^{\mathrm{a}}$ & 96 & ,000 & 1,722 \\
\hline
\end{tabular}

Sumber: Data Olahan 


\section{Pengaruh Kesadaran Wajib Pajak, Pelayanan Fiskus, dan Sanksi Pajak; Januar Dio

Dari hasil perhitungan menggunakann IBM SPSS Versi 21 didapat nilai Durbin Watson dalam penelitian ini sebesar 1,722. Karena nilai DW berasal pada nilai 1,66-2,34. Dapat disimpulkan bahwa model yang dikembangkan tidak ada autokorelasi.

\section{Analisis Regresi Berganda}

Analisis uji regresi berganda bertujuan untuk menguji pengaruh kesadaran wajib pajak, pelayanan fiskus dan sanksi pajak terhadap kepatuhan wajib pajak pada wajib pajak orang pribadi yang melakukan kegiatan usaha dan pekerjaan bebas. Berdasarkan hasil regresi berganda dengan menggunakan bantuan program SPSS versi 21.0 diperoleh koefisien regresi sebagai berikut :

Tabel 5 Uji Koefisien Regresi

\section{Coefficients $^{\mathrm{a}}$}

\begin{tabular}{|c|c|c|c|c|c|c|}
\hline \multirow{2}{*}{\multicolumn{2}{|c|}{ Model }} & \multicolumn{2}{|c|}{$\begin{array}{c}\text { Unstandardized } \\
\text { Coefficients }\end{array}$} & \multirow{2}{*}{$\begin{array}{c}\begin{array}{c}\text { Standardized } \\
\text { Coefficients }\end{array} \\
\text { Beta }\end{array}$} & \multirow[t]{2}{*}{$\mathbf{T}$} & \multirow[t]{2}{*}{ Sig. } \\
\hline & & B & Std. Error & & & \\
\hline \multirow{5}{*}{1} & (Constant) & $-2,679$ & 5,197 & &,- 516 & 607 \\
\hline & Kesadaran Wajib pajak & ,530 & ,236 & ,214 & 2,242 & ,027 \\
\hline & Pelayanan Fiskus &,- 011 & ,148 &,- 007 &,- 076 & ,940 \\
\hline & Sanksi Pajak & ,654 & ,158 & ,395 & 4,130 &, 000 \\
\hline & $\begin{array}{l}\mathrm{R}^{2}=0,266 \\
\text { Adjusted } \mathrm{R}^{2}=0,243 \\
* \text { Sig }=0,05\end{array}$ & \multicolumn{3}{|r|}{$\begin{array}{l}F=2,70 \\
\text { Sig } F=0,000^{*}\end{array}$} & \multicolumn{2}{|c|}{$\alpha=-2,679$} \\
\hline
\end{tabular}

Sumber: Data Olahan

Berdasarkan hasil di atas, maka diperoleh persamaan sebagai berikut:

$$
\mathrm{Y}=-2,679+0,530 \mathrm{X} 1-0,011 \mathrm{X} 2+0,654 \mathrm{X} 3+\mathrm{e}
$$

Pada tabel di atas dijelaskan hasil analisis koefisien regresi sebagai berikut :

1. Konstanta sebesar -2,679 artinya jika Kesadaran Wajib Pajak (X1), Pelayanan Fiskus (X2) dan Sanksi Pajak (X3) bernilai nol, maka Kepatuhan Wajib Pajak (Y) adalah bernilai -2,679.

2. Koefisien variabel Kesadaran Wajib Pajak (X1) sebesar 0,530. Artinya jika variabel eksogen (terikat) lainnya bernilai tetap dan variabel Kesadaran Wajib Pajak (X1) mengalami kenaikan 1 satuan, maka variabel Kepatuhan Wajib Pajak (Y) akan mengalami kenaikan sebesar 0,530. Jadi hubungan Kesadaran Wajib Pajak ke Kepatuhan Wajib Pajak bernilai positif.

3. Koefisien variabel Pelayanan Fiskus (X2) sebesar -0,011. Artinya jika variabel eksogen (terikat) lainnya bernilai tetap dan variabel Pelayanan Fiskus (X2) mengalami kenaikan 1 satuan, maka variabel Kepatuhan Wajib Pajak (Y) akan mengalami penurunan sebesar -0,011. Jadi hubungan Pelayanan Fiskus ke Kepatuhan Wajib Pajak bernilai negatif.

4. Koefisien variabel Sanksi Pajak (X3) sebesar 0,654. Artinya jika variabel eksogen (terikat) lainnya bernilai tetap dan variabel Sanksi Pajak (X3) mengalami kenaikan 1 satuan, maka variabel Kepatuhan Wajib Pajak (Y) akan mengalami kenaikan sebesar 0,654. Jadi hubungan Sanksi Pajak ke Kepatuhan Wajib Pajak bernilai positif.

\section{Pengujian Hipotesis}

\section{Uji Signifikansi Parameter Simultan (Uji Statistik F)}

Berdasarkan pada tabel 5 diketahui bahwa $f$ tabel pada penelitian ini yaitu 2,70 sedangkan tingkat signifikansi sebesar $0,00<0,05$ yang berarti semua variabel independen yang dimasukkan yakni Kesadaran Wajib Pajak, Pelayanan Fiskus dan Sanksi Pajak dalam model ini mempunyai pengaruh secara bersama-sama terhadap variabel dependen yakni Kepatuhan Wajib Pajak.. 


\section{Uji Signifikansi Parameter Individual (Uji Statistik t)} berikut:

Hasil uji t pada tabel 5 memperlihatkan nilai t dan probabilitas masing-masing dijelaskan sebagai

a. Variabel kesadaran wajib pajak memperlihatkan nilai t sebesar 2,242 dan signifikan 0,027. Pada alpha 0,05 dan df n-k (100-4) nilai t tabel 1,985 maka disimpulkan bahwa variabel kesadaran wajib pajak berpengaruh signifikan secara parsial terhadap kepatuhan wajib pajak.

b. Variabel pelayanan fiskus memperlihatkan nilai t sebesar -0,076 dan signifikan 0,940. Pada alpha 0,05 dan df $n-k$ (100-4) nilai t tabel 1,985 maka disimpulkan bahwa variabel pelayanan fiskusberpengaruh tidak signifikan secara parsial terhadap kepatuhan wajib pajak.

c. Variabel sanksi pajak memperlihatkan nilai t sebesar 4,130 dan signifikan 0,000. Pada alpha 0,05 dan df $\mathrm{n}$-k (100-4) nilai t tabel 1,985 maka disimpulkan bahwa variabel sanksi pajak berpengaruh signifikan secara parsial terhadap kepatuhan wajib pajak.

\section{Uji Koefisien Determinasi $\left(\mathbf{R}^{2}\right)$}

Berdasarkan tabel 5 dapat disimpulkan bahwa nilai $R^{2}$ yang diperoleh sebesar 0,266 sehingga dapat disimpulkan bahwa Kepatuhan Wajib Pajak di Kota Samarinda dipengaruhi oleh variabel Kesadaran Wajib Pajak, Pelayanan Fiskus dan Sanksi Pajak sebesar 26,6\%, sedangkan sisanya 73,4\% dijelaskan oleh variabel lain yang tidak termasuk dalam penelitian ini. Variabel independen lain yang mungkin dapat menjelaskan variabel dependen antara lain, tingkat penghasilan wajib pajak, persepsi efektifitas sistem perpajakan, tarif pajak, kondisi sistem administrasi pajak suatu negara, biaya kepatuhan dan tanggung jawab moral.

\section{Pembahasan}

\section{Pengaruh Kesadaran Wajib Pajak Terhadap Kepatuhan Wajib Pajak}

Hipotesis pertama (H1) menyatakan bahwa kesadaran wajib pajak berpengaruh positif terhadap kepatuhan wajib pajak. Berdasarkan hasil pengujian hipotesis variabel kesadaran wajib pajak terhadap kepatuhan wajib pajak, menunjukkan bahwa kesadaran wajib pajak berpengaruh signifikan dan mempunyai hubungan positif terhadap kepatuhan wajib pajak. Berdasarkan hasil pengujian hipotesis menunjukkan bahwa hipotesis pertama (H1) diterima. Hal ini menunjukkan wajib pajak telah sadar dan paham akan pentingnya membayar pajak guna kepentingan bersama.

Kesadaran wajib pajak akan meningkat bilamana wajib pajak tersebut berpersepsi baik terhadap pajak itu sendiri. Kesadaran wajib pajak akan tumbuh dengan sendirinya jika wajib pajak itu mengetahui manfaat yang diberikan dari fungsi pajak tersebut. Dengan diterapkan self assessment system akan memberikan perubahan sikap kesadaran masyarakat dalam membayar pajak secara sukarela tanpa ada paksaan dari petugas fiskus. Hasil penelitian ini konsisten dengan penelitian yang telah dilakukan oleh Nugroho (2012), dan Indriyani (2014) yang menunjukkan bahwa kesadaran wajib pajak berpengaruh positif terhadap kepatuhan wajib pajak.

\section{Pengaruh Pelayanan Fiskus Terhadap Kepatuhan Wajib Pajak}

Hipotesis kedua (H2) menyatakan bahwa kualitas pelayanan berpengaruh positif terhadap kepatuhan wajib pajak. Hasil pengujian hipotesis pelayanan fiskus terhadap kepatuhan wajib pajak, menunjukkan bahwa pelayanan fiskus berpengaruh tidak signifikan dan mempunyai hubungan negatif terhadap kepatuhan wajib. Berdasarkan hasil tersebut menunjukkan bahwa hipotesis kedua (H2) ditolak. Hal ini berarti bahwa kualitas pelayanan tidak berpengaruh signifikan terhadap kepatuhan wajib pajak. Hasil penelitian ini ternyata tidak konsisten dengan penelitian yang telah dilakukan oleh Arum (2012), dan Winerungan (2013) yang menunjukkan bahwa kualitas pelayanan berpengaruh positif terhadap kepatuhan wajib pajak.

Hasil penelitian ini mengindikasikan bahwa kualitas pelayanan masih belum dapat meningkatkan kepatuhan wajib pajak dalam melaksanakan kewajiban membayar dan melaporkan pajaknya. Hal ini dapat 


\section{Pengaruh Kesadaran Wajib Pajak, Pelayanan Fiskus, dan Sanksi Pajak; Januar Dio}

terjadi karena kualitas pelayanan dari aparat pajak belum dapat memenuhi atau melebihi harapan wajib pajak. Aparat pajak terus berupaya meningkatkan pelayanan melalui perkembangan teknologi informasi dengan tersedianya fasilitas $e-S P T$ dan $e$-filling. Masih banyak wajib pajak yang belum memahami bagaimana menggunakan e-SPTdan e-filling karena untuk mengisi formulir SPT manual saja masih banyak yang kesulitan. Selain itu, keterbatasan Sumber Daya Manusia (SDM) dan fasilitas yang dimiliki oleh wajib pajak menjadi hambatan untuk dapat mengaksesnya. Aparat pajak perlu melakukan strategi khusus untuk mengatasi permasalahan tersebut sehingga dapat meningkatkan kepatuhan wajib pajak

\section{Pengaruh Sanksi Pajak Terhadap Kepatuhan Wajib Pajak}

Hipotesis ketiga (H3) menyatakan bahwa sansi pajak berpengaruh positif terhadap kepatuhan wajib pajak. Hasil pengujian hipotesis variabel sanksi pajak terhadap kepatuhan wajib, menunjukkan bahwa sanksi pajak berpengaruh signifikan dan mempunyai hubungan positif terhadap kepatuhan wajib pajak. Berdasarkan hasil tersebut menunjukkan bahwa hipotesis ketiga (H3) diterima. Hal ini menunjukkan wajib pajak tidak ingin dikenakan sanksi pajak apabila mereka tidak menunaikan kewajiban perpajakannnya.

Sanksi perpajakan harus dikenakan bagi wajib pajak yang melakukan kecurangan dan yang enggan membayar pajak. Sanksi pajak harus lebih diperketat peraturannya, supaya wajib pajak akan merasa takut jika tidak membayar pajak dan akan melakukan perhitungan pajak sesuai dengan penghasilan yang diperoleh. Sanksi perpajakan dapat menjadi motivasi dalam meningkatkan kepatuhan wajib pajak dalam membayar pajak. Hasil penelitian ini konsisten dengan penelitian yang telah dilakukan oleh Arum (2012), dan Indriyani (2014) yang menunjukkan bahwa sanksi pajak berpengaruh positif terhadap kepatuhan wajib pajak.

\section{SIMPULAN}

Berdasarkan hasil penelitian dan pembahasan yang dilakukan oleh penulis serta data-data penelitian yang diperoleh selama penelitian, maka ditarik kesimpulan sebagai berikut:

1. Kesadaran Wajib Pajak berpengaruh signifikan dan mempunyai hubungan positif terhadap Kepatuhan Wajib Pajak yang terdaftar di Kantor Pelayanan Pajak Pratama Samarinda. Hal ini menunjukkan bahwa semakin tinggi kesadaran wajib pajak maka semakin tinggi pula tingkat kepatuhan wajib pajak.

2. Pelayanan Fiskus berpengaruh tidak signifikan dan mempunyai hubungan negatif terhadap Kepatuhan Wajib Pajak yang terdaftar di Kantor Pelayanan Pajak Pratama Samarinda. Hal ini menunjukkan bahwa pelayanan baik saja oleh fiskus belum tentu akan meningkatkan kepatuhan wajib pajak.

3. Sanksi Pajak berpengaruh signifikan dan mempunyai hubungan positif terhadap Kepatuhan Wajib Pajak yang terdaftar di Kantor Pelayanan Pajak Pratama Samarinda. Hal ini menunjukkan bahwa dengan diterapkannya sanksi pajak maka akan meningkatkan kepatuhan wajib pajak.

\section{SARAN}

Berdasarkan hasil penelitian, pembahasan dan kesimpulan yang telah dijabarkan sebelumnya, maka penulis memberikan beberapa saran sebagai berikut:

1. Wajib pajak diharapkan dapat terus aktif untuk belajar perpajakan agar pemahaman mengenai peraturan perpajakan semakin meningkat demi terwujudnya pelaksanaan self assessment system yang lebih baik. Dengan adanya self assessment system dapat memberikan perubahan sikap kesadaran masyarakat dalam membayar pajak secara sukarela tanpa ada paksaan dari petugas fiskus.

2. Petugas pajak harus lebih aktif dalam memberikan pelayanan kepada wajib pajak, juga terus melakukan sosialisasi tentang peraturan perpajakan maupun pengenalan terhadap perangkat perpajakan yang berbasis online sehingga dapat meningkatkan kepatuhan wajib pajak dalam memenuhi kewajibannya.

3. Sanksi pajak harus lebih diperketat peraturannya, supaya wajib pajak akan merasa takut jika tidak membayar pajak dan akan melakukan perhitungan pajak sesuai dengan penghasilan yang diperoleh.

Copyright (C) 2017, FORUM EKONOMI ISSN Print: 1411-1713 ISSN Online: 2528-150X 
Dengan adanya sanksi perpajakan dapat menjadi motivasi dalam meningkatkan kepatuhan wajib pajak dalam membayar pajak.

4. Hasil penelitian ini diharapkan dapat bermanfaat bagi Direktorat Jenderal Pajak, diharapkan dengan adanya penelitian ini dapat menjadi masukan untuk pengambilan keputusan mengenai kebijakan perpajakan bagi Wajib Pajak di Samarinda di masa mendatang. Penulis juga berharap bahwa penelitian ini dapat memberikan informasi sedemikian rupa kepada pihak yang berkepentingan serta dapat digunakan sebagai bahan pembanding untuk penelitian selanjutnya. Di samping itu, penelitian ini diharapkan mampu mendorong peneliti selanjutnya untuk mengamati faktor-faktor lain yang dapat mempengaruhi kepatuhan Wajib Pajak di Samarinda, seperti tingkat penghasilan wajib pajak, persepsi efektifitas sistem perpajakan, tarif pajak, kondisi sistem administrasi pajak suatu negara, biaya kepatuhan dan tanggung jawab moral.

\section{DAFTAR PUSTAKA}

Alfigari. 2000. Analisis Regresi, Teori, Kasus, \& Solusi. BPFE UGM. Yogyakarta

Ajzen, Icek. 2005. Attitudes, Personality and Behavior. England: Open University Press, McGraw-Hill Education.

Arum, Harjanti Puspa. 2012. Pengaruh Kesadaran Wajib Pajak, Pelayanan Fiskus, Dan Sanksi Pajak Terhadap Kepatuhan Wajib Pajak Orang Pribadi Yang Melakukan Kegiatan Usaha Dan Pekerjaan Bebas (Studi DI Wilayah KPP Pratama Cilacap). Skripsi. Semarang: Universitas Diponegoro.

Badan Pusat Statistik. 2010-2014. Statistik Indonesia. BPS - Statistics Indonesia.

Boediono, B. 2003. Pelayanan Prima Perpajakan. Jakarta: Rineka Cipta.

Devano Sony, Siti Kurnia Rahayu. 2006. Perpajakan: Konsep, Teori, dan Isu. Jakarta: Prenada Media Group.

Direktorat Jenderal Pajak. 2008. Undang-Undang Nomor 28 Tahun 2007 tentang Ketentuan Umum dan Tata Cara Perpajakan. Sumber: Belajar Pajak UU KUP No. 28 Tahun 2007 - PajakOnline.htm

2015. Seminar: PMK Nomor 91/PMK.03/2015 Tentang Pengurangan Atau Penghapusan Sanksi Administrasi Atas Keterlambatan Penyampaian Surat Pemberitahuan, Pembetulan Surat Pemberitahuan, Dan Keterlambatan Pembayaran Atau Penyetoran Pajak. Oleh: Inra Kelana Bayu di Hotel Mesra Samarinda. 8 Agustus 2015.

Fikriningrum, Winda Kurnia. 2012. Analisis Faktor-Faktor Yang Mempengaruhi Wajib Pajak Orang Pribadi Dalam Memenuhi Kewajiban Membayar Pajak (Studi Kasus Pada Kantor Pelayanan Pajak Pratama Semarang Candisari). Skripsi. Semarang: Universitas Diponegoro.

Gozali, Imam. 2011. Aplikasi Analisis Multivariate dengan Program SPSS. Badan Penerbit UNDIP. Semarang.

Gujarati, Damonar R. 2001. Ekonometrika Dasar. Jakarta: Erlangga.

Gunadi. 2005. Kebijakan Pemeriksaan Pajak Pasca Berlakunya Undang Undang Perpajakan Baru, Berita Pajak

Hardiningsih, Pancawati dan Nila Yuliniawati. 2011. Faktor-Faktor Yang Mempengaruhi Kemauan Membayar Pajak. Skripsi. Semarang : Universitas Stikubank.

Ilyas, Wirawan B. dan Richard Burton. 2010. Hukum Pajak (Edisi 5). Penerbit Salemba Empat.

Indriyani, Putu Arika dan I Made Sukartha. 2014. Tanggung Jawab Moral, Kesadaran Wajib Pajak, Sanksi Perpajakan Dan Kualitas Pelayanan Pada Kepatuhan Pelaporan Wajib Pajak Badan.Skripsi. Denpasar : Universitas Udayana. 


\section{Pengaruh Kesadaran Wajib Pajak, Pelayanan Fiskus, dan Sanksi Pajak; Januar Dio}

Jatmiko, Agus Nugroho. 2006. Pengaruh Sikap Wajib Pajak pada Pelaksanaan Sanksi Denda, Pelayanan Fiskus dan Kesadaran Perpajakan terhadap Kewajban Wajib Pajak: Studi Empiris Terhadap Wajib Pajak. Tesis. Semarang. Universitas Diponegoro.

Jotopurnomo, Cindy dan Yenni Mangoting. Pengaruh Kesadaran Wajib Pajak, Kualitas Pelayanan Fiskus, Sanksi Perpajakan, Lingkungan Wajib Pajak Berada terhadap Kepatuhan Wajib Pajak Orang Pribadi di Surabaya. Skripsi. Surabaya : Universitas Kristen Petra

Kaltim Post. 2015. Tunggakan di Kaltim Rp 3 Triliun. Kaltim Post, 12 Desember 2015. h. 33. . 2016. KPP Diminta Fokus Kawal Pengusaha. Kaltim Post. 30 Januari 2016. h. 39 . 2016b.Laporan Pajak Rita Terbesar. Kaltim Post. 18 Maret 2016. h. 33

Kantor Pajak Pratama. 2012-2015. Sistem Informasi Direktorat Jenderal Pajak. Samarinda. KPP

Lupiyoadi, Hamdani. 2006. "Manajemen Pemasaran Jasa, Edisi Kedua. Jakarta: Salemba Empat.

Mardiasmo. 2011. Perpajakan: Edisi Revisi 2011. Yogyakarta: CV. Andi Offset.

Masruroh, Siti dan Zulaikha. 2013. Pengaruh Kemanfaaatan Npwp, Pemahaman Wajib Pajak, Kualitas Pelayanan, Sanksi Perpajakan Terhadap Kepatuhan Wajib Pajak (Studi Empiris Pada Wp Op Di Kabupaten Tegal). Skripsi. Semarang: Universitas Diponegoro

Muljono, Djoko. 2008. Pajak Pertambahan Nilai. Penerbit Andi. Yogyakarta . 2011. Siapa Bilang Lapor Pajak Memusingkan?. Penerbit Andi. Yogyakarta.

Muliari, Ni Ketut dan Putu Ery Setiawan. 2009. Pengaruh Persepsi Tentang Sanksi Perpajakan dan Kesadaran Wajib Pajak Orang Pribadi di Kantor Pelayanan Pajak Pratama Denpasar Timur. Skripsi. Denpasar: Universitas Udayana.

Munari. 2005. Pengaruh Faktor Tax Player Terhadap Keberhasilan Penerimaan Pajak Penghasilan (Studi Kasus KPP Batu, Malang)’. Jurnal Eksekutif, Vol.2, No.2

Mustikasari, Elia. 2007. Kajian Empiris tentang Kepatuhan Wajib Pajak Badan di Perusahaan Industri Pengolahan di Surabaya. Simposium Nasional Akuntansi X, Makassar.

Nisaputra, Rezkiana. 2014. Tingkat Kesadaran Masyarakat Membayar Pajak Masih Rendah. http://www.infobanknews.com, diakses tanggal 20 Maret 2016.

Nugroho, Rahman Adi. 2012. Faktor-Faktor Yang Mempengaruhi Kemauan Untuk Membayar Pajak Dengan Kesadaran Membayar Pajak Sebagai Variabel Intervening (Studi Kasus Wajib Pajak Orang Pribadi Yang Melakukan Pekerjaan Bebas Yang Terdaftar Di KPP Pratama Semarang Tengah Satu). Skripsi. Semarang : Universitas Diponegoro.

Nurmantu, Safri. 2005. Pengantar Perpajakan. Jakarta: Granit.

Peraturan Menteri Keuangan Nomor 74/PMK.03/2012 Tentang Tata Cara Penetapan Dan Pencabutan Penetapan Wajib Pajak Dengan Kriteria Tertentu Dalam Rangka Pengembalian Pendahuluan Kelebihan Pembayaran Pajak.

Purwono, Herry. Dasar-Dasar Perpajakan Dan Akuntansi Pajaki, Penerbit Erlangga, 2010.

Resmi, Siti. Perpajakan: Teori Dan Kasus, Jakarta: Salemba Empat, 2009.

Robbins, Stephen P, Timothy A. Judge. 2009. Perilaku Organisasi Buku 1. Jakarta: Salemba Empat,

Santi, Anisa Nirmala. 2012. Analisis Pengaruh Kesadaran Perpajakan, Sikap Rasional, Lingkungan, Sanksi Denda dan Sikap Fiskus Terhadap Kepatuhan Wajib Pajak (Studi Empiris Pada WPOP di Wilayah KPP Pratama Semarang). Skripsi. Semarang: Universitas Diponegoro.

Simanjuntak, Timbul Hamonangan dan Mukhlis Imam. 2012. Dimensi Ekonomi Perpajakan dalam Pembangunan Ekonomi. Jakarta:Raih Asa Sukses

Sofyan, Marcus Taufan. 2005. Pengaruh Penerapan Sistem Administrasi Perpajakan Modern Terhadap Kepatuhan Wajib Pajak. Tanggerang:Sekolah Tinggi Akuntansi Negara.

Copyright @ 2 2017, FORUM EKONOMI ISSN Print: 1411-1713 ISSN Online: 2528-150X 
Sudjana. 2000. Metode Statistik. Tarsito: Bandung.

Suryadi. 2006. Model Hubungan Kausal Kesadaran, Pelayanan, Kepatuhan Wajib Pajak Dan Pengaruhnya Terhadap Kinerja Penerimaan Pajak: Suatu Survei Di Wilayah Jawa Timur. Jurnal Keuangan Publik, Vol. 4, No. 1.

Suhendra, Euphrasia Susy. 2010. Pengaruh Tingkat Kepatuhan Wajib Pajak Badan Terhadap Peningkatan Penerimaan Pajak Penghasilan Badan. Skripsi. Jakarta : Universitas Gunadarma.

Siti Kurnia Rahayu, 2010. Perpajakan Indonesia: Konsep dan Aspek Formal. Yogyakarta: Graha Ilmu

Sugiyono. 2012. "Memahami Penelitian Kualitatif”. Bandung: ALFABETA.

Supramono \& Damayanti, Theresia Woro. 2010. Perpajakan Indonesia: Mekanisme dan Perhitungan. CV. Andi Offset, Yogyakarta.

Undang-Undang Nomor 16 Tahun 2009 tentang Ketentuan Umum dan Tata Cara Perpajakan.

Undang-Undang Nomor 28 Tahun 2007 tentang Ketentuan Umum dan Tata Cara Perpajakan.

Widarjono, Agus. 2005. Ekonometrika Teori dan Aplikasinya. Yogyakarta.

Widayati Dan Nurlis. 2010. Faktor-Faktor Yang Mempengaruhi Kemauan Untuk Membayar Pajak Wajib Pajak Orang Pribadi Yang Melakukan Pekerjaan Bebas (Studi Kasus Pada KPP Pratama Gambir Tiga). Simposium Nasional Akuntansi XIII. Purwokerto

Winerungan, Oktaviane Lidya. 2013. Sosialisasi Perpajakan, Pelayanan Fiskus Dan Sanksi Perpajakan Terhadap Kepatuhan WPOP Di KPP Manado Dan KPP Bitung. Skripsi. Manado : Universitas Sam Ratulangi.

Yadnyana, I Ketut. 2009. Pengaruh Moral dan Sikap Wajib Pajak pada Kepatuhan Wajib Pajak Koperasi di Kota Denpasar. Skripsi. Denpasar: Universitas Udayana. 